\title{
Purification and Properties of a Thermo-labile Antigen from Baker's Yeast Cells*
}

\author{
Youichi Tamai, Hiroshi ShInmoto and Masayoshi TakakuWa \\ Department of Agricultural Chemistry, Faculty of Agriculture, \\ Ehime University, Matsuyama 790, Japan
}

Received December 16,1980

\begin{abstract}
A thermo-labile antigen (TLA) on the yeast cell surface was isolated from a yeast cell autolyzate and purified to a homogeneous state by chromatography on an immunoadsorbent affinity column. The molecular weight of TLA was about $1.45 \times 10^{5}$ on SDS-polyacrylamide gel electrophoresis and about $1.5 \times 10^{5}$ on gel chromatography on Sephadex G-200. The TLA contained $74.5 \%$ protein and $25.5 \%$ sugar. It was characterized by high contents of glycine, glutamic acid, serine and aspartic acid. Half-cystine, methionine, histidine and arginine were not found. The sugar moiety was composed of galactose, mannose, $N$-acetylglucosamine and fucose. The antigenic determinant of TLA was distinct from that of cell wall mannan in the Ouchterlony immunodiffusion test. No precipitin line against anti-TLA serum was observed, when TLA was heated at $90^{\circ} \mathrm{C}$ for $10 \mathrm{~min}$. Oxidation with periodate had little effect on antigenicity, but digestion with Pronase or treatment with protein denaturants resulted in ioss of the antigenicity. These results suggest that the protein moiety plays an important role as the antigenic determinant of TLA. Moreover, the antiserum specific to TLA agglutinated fresh yeast cells, and the distribution of TLA was apparent on the yeast cell surface by immunofluorescence staining. These findings suggest that TLA molecules were exposed on the outer surface of the yeast cell wall.
\end{abstract}

The antigenic material of the yeast cell surface has been recognized to be a cell wall mannan and antigenic structures for it were proposed by Peat et al. ${ }^{1)}$ Ballou $^{2)}$ and Suzuki et $a l .{ }^{3)}$ Tsuchiya established a method of serological taxonomy of yeast, and reported that some thermo-labile antigens involved in cell agglutination reactions might be located on the surface of yeast cells. ${ }^{4}$ In the previous papers, ${ }^{5 \sim 7}$ we reported that chemical modification of the yeast cell surface with such reagents as diethyl pyrocarbonate (DEPC), formaldehyde and trinitrobenzenesulfonate (TNBS), or heating $\left(100^{\circ} \mathrm{C}, 10 \mathrm{~min}\right)$ of yeast cells resulted in lowering of the antigenicity of yeast cells, and that even mannan prepared under mild experimental conditions did not show complete absorption of antibody with the antiserum against fresh yeast cells. These results suggest that there are some kinds of

* Immunochemical Studies on Surface of Yeast Cell. Part V. For Part IV, see ref. 7. antigen other than mannan. Therefore, an attempt was made to isolate unidentified antigenic materials of the yeast cell surface, and glycoproteins having the antigenic activity were found to be present in the acetone precipitate from a yeast cell autolyzate or Zymolyase digest of yeast cells. The present paper deals with the purification of a thermolabile antigen (TLA) from baker's yeast cells, and some chemical and immunochemical properties of the antigen.

\section{MATERIALS AND METHODS}

Materials. Pressed baker's yeast (Saccharomyces cerevisiae) with no additives was obtained from Oriental Baker's Yeast Co. and stored at $0 \sim 5^{\circ} \mathrm{C}$, and within a month after arrival, the yeast was used as fresh. Yeast mannan was prepared from the pressed yeast by the method of Edwards ${ }^{8)}$ (named the mannan-preparation). Anti-yeast serum was prepared according to the previous report. ${ }^{5)} \mathrm{CNBr}$-activated Sepharose $4 \mathrm{~B}$ was purchased from Pharmacia Fine Chemicals (Sweden), Pronase E from Kakenkagaku Co., and FITC-labeled anti-rabbit 
IgG serum from Igaku Seibutsugaku Lab. All other chemicals used were of the purest grade available.

Autolysate prepared by treatment with acetic acid. The pressed baker's yeast $(200 \mathrm{~g})$ was exposed to acetic acid vapour at $30^{\circ} \mathrm{C}$ for 2 days. The autolysate was mixed with $100 \mathrm{ml}$ of water, the $\mathrm{pH}$ adjusted to 7.0 with $8 \mathrm{~N}$ sodium hydroxide, and the mixture allowed to stand at $30^{\circ} \mathrm{C}$ for 3 days. The mixture was centrifuged at $8000 \times g$ for $30 \mathrm{~min}$, and acetone $(80 \mathrm{ml})$ was added to the supernatant $(160 \mathrm{ml})$ in an ice bath with gentle stirring. After standing for 10 min, the precipitate was collected by centrifuging at $8000 \times g$ for $30 \mathrm{~min}$. The precipitate was dissolved in water (about $50 \mathrm{ml}$ ) and dialyzed against water with frequent stirring for $3 \mathrm{hr}$. The insoluble material arising during the dialysis was removed by centrifuging at $8000 \times g$ for 30 min, and the supernatant was lyophilized (named the acetone-preparation).

Enzyme digest. Zymolyase 60,000 was used as a lytic enzyme. The lysis of yeast cells with the enzyme was performed according to the procedures reported previously. ${ }^{7)}$ The enzyme digest was centrifuged at $8000 \times \mathrm{g}$ for $30 \mathrm{~min}$ and the supernatant was concentrated under reduced pressure with a rotary evaporator.

Methods. Immunodiffusion and immunoelectrophoresis. Immunodiffusion was carried out $1 \%$ agar gel by the methods of Ouchterlony. "9) Immunoelectrophoresis was conducted in $1 \%$ agarose at $5 \mathrm{~mA}$ per plate $(2.5 \times 7.5$ $\mathrm{cm}$ ) for $60 \mathrm{~min}$ in $50 \mathrm{~mm}$ veronal buffer $(\mathrm{pH} 8.0)$.

Estimation of molecular weight by gel chromatography and by SDS-polyacrylamide gel electrophoresis. Estimation of the molecular weight of TLA by gel filtration was performed according to the method of Andrews ${ }^{10)}$ with a column $(1.8 \times 85 \mathrm{~cm})$ of Sephadex G-200, which had previously been equilibrated with $0.01 \mathrm{M}$ Tris- $\mathrm{HCl}$ buffer (pH 7.0) and calibrated with standard proteins. SDSelectrophoresis was performed according to the procedure of Weber and Osborn. ${ }^{11}$

Protein and sugar contents. Protein was determined by the method of Lowry et al., ${ }^{12)}$ using bovine serum albumin as standard, and sugar content was determined by the phenol-sulfuric acid method ${ }^{13)}$ using glucose as standard.

Amino acid analysis. Hydrolysis was performed with $6 \mathrm{~N}$ hydrochloric acid in an evacuated sealed tube at $110^{\circ} \mathrm{C}$ for $24 \mathrm{hr}$. Analysis was performed with an automatic amino acid analyzer (Hitachi KLA-5) using the method of Spackman et al. ${ }^{14)}$ No correction was made for the amounts of serine, threonine and tyrosine destroyed during the acid hydrolysis.

Sugar analysis. The composition of the sugar moiety of TLA was determined by gas liquid chromatography. Methanolysis and re- $N$-acetylation of TLA and authentic monosaccharides were carried out according to the method of Chambers et al. ${ }^{15)}$ Methyl glycosides were converted into trimethylsylyl (TMS)-derivatives by the method of Sweeley et al. ${ }^{16)}$ Gas liquid chromatography (GLC) was performed with a Yanagimoto model G-180 equipped with a hydrogen flame ionization detector. A glass column $(200 \times 0.3 \mathrm{~cm})$ packed with $1.5 \%$ SE-30 was employed, and oxygen-free nitrogen was used as carrier gas $(20 \mathrm{ml} / \mathrm{min})$. The temperature program was from 120 to $250^{\circ} \mathrm{C}$ at the rate of $5^{\circ} \mathrm{C} / \mathrm{min}$.

Oxidation with periodate (periodate-oxidation). Various samples $(200 \mu \mathrm{g})$ were dissolved in $0.9 \mathrm{ml}$ each of water and $0.1 \mathrm{ml}$ of $0.2 \mathrm{M}$ sodium periodated was added. Each mixture was incubated in the dark at $0^{\circ} \mathrm{C}$ for $6 \mathrm{hr}$. At appropriate intervals, aliquots $(5 \mu)$ were taken for assay of antigenic activity by the immunodiffusion method which was carried out at $4^{\circ} \mathrm{C}$ for 2 days.

Digestion with "Pronase E" (Pronase-digestion). Various samples $(200 \mu \mathrm{g})$ were dissolved in $0.9 \mathrm{ml}$ each of $0.025 \mathrm{M}$ Tris-HCl buffer ( $\mathrm{pH} 7.0$ ), $10 \mu$ l of Pronase (1 $\mathrm{mg} / \mathrm{ml}$ ) was added, and the mixture incubated at $37^{\circ} \mathrm{C}$ for $6 \mathrm{hr}$. At appropriate intervals, aliquots $(5 \mu \mathrm{l})$ were taken and their antigenic activities were assayed. Immunodiffusion was carried out at $4^{\circ} \mathrm{C}$ for 2 days. The Pronase contained in the digest did not affect the formation of precipitin lines.

Estimation of antigenicity. The antigenicity of the yeast cell surface was estimated from the capacity of yeast cells to absorb antibodies from the antiserum, according to the method reported previously. ${ }^{5)}$ Antigenicity of mannan and TLA preparations was investigated by Ouchterlony's double immunodiffusion test using anti-yeast serum and anti-TLA serum, respectively, unless otherwise stated.

Immunofiuorescence staining. Yeast cells were incubated with anti-TLA serum at $37^{\circ} \mathrm{C}$ for $60 \mathrm{~min}$ and washed three times with saline by centrifugation. Fluorescent isothiocyanate (FITC)-labeled anti-rabbit IgG serum was added to the sedimented cells and the suspension was incubated at $37^{\circ} \mathrm{C}$ for $30 \mathrm{~min}$. After the cells had been washed three times with saline, one drop of the cell suspension was placed on an object glass sheet and observed under fluorescence microscope.

Anti-TLA serum. The acetone-preparation was dissolved in water $(1 \mathrm{mg} / \mathrm{ml})$ and an aliquot $(5 \mu / /$ well $)$ was placed in the antigen well on an agar plate. After electrophoresis, anti-yeast serum was poured into the antibody ditch on the plate and allowed to stand at $4^{\circ} \mathrm{C}$ for 2 days. After precipitin lines had been formed, the agar plates were rinsed with saline at room temperature for 3 days to remove non-recipitable contaminants. One of the precipitin lines which were not formed in the heated sample, as indicated by an arrow in Fig. 1, was cut out 
from the plate, and crushed with a glass rod. The agar pieces cut out from twenty plates were used for one immunization. The first immunization was carried out on a rabbit by subcutaneous injection in the back, as an emulsion in Freund's complete adjuvant (Difco Lab. Inc., U.S.A.). After 10 days from the first immunization, the suspension of crushed agar pieces was injected intravenously and similar immunization was repeated 6 times at 7 day intervals. The animal was bled 10 days after the final injection, and antiserum was prepared.

Preparation of immunoadsorbent. Immunoglobulin fraction ( $80 \mathrm{mg}$ as protein), precipitated by $43 \%$ saturated ammonium sulfate from the anti-TLA serum, was coupled to Sepharose $4 \mathrm{~B}(10 \mathrm{ml})$ activated with $\mathrm{CNBr}$ according to the method of Igarashi et al. ${ }^{171}$

\section{RESULTS}

\section{Immunoelectrophoresis of yeast extracts}

The presence of TLA in the acetonepreparation or Zymolyase digest was investigated by immunoelectrophoresis. Figure 1 shows the immunoelectrophoresis of two kinds of preparation. The anti-yeast serum gave clear precipitin lines against mannan contained in the samples. Several other precipitin lines, however, were observed at the anode side and these lines were not detected in the heated samples. The most distinct line appeared nearest to the center well for both unheated samples. Therefore, the isolation of this thermo-labile antigenic substance was attempted by immunoadsorbent affinity column chromatography.

\section{Purification of TLA}

1. DEAE-cellulose column chromatography. The TLA in the acetone-preparation was partially purified on a DEAE-cellulose column prior to applying on the immunoadsorbent affinity column. The acetonepreparation $(250 \mathrm{mg})$ was dissolved in $0.05 \mathrm{M}$ Tris- $\mathrm{HCl}$ buffer ( $\mathrm{pH} 7.0$ ) containing 2 mm zinc sulfate, since zinc ions were found to stabilize the antigenic activity of TLA. The solution was applied to a column $(1.5 \times 10 \mathrm{~cm})$ of DEAE-cellulose equilibrated with the same buffer ( $\mathrm{pH} 7.0)$. The column was washed with the same buffer and then successively eluted with $200 \mathrm{ml}$ of $0.05 \mathrm{M}$ sodium chloride and $200 \mathrm{ml}$ of $0.1 \mathrm{M}$ sodium chloride dissolved in the same buffer. TLA appeared in the fraction eluted with $0.1 \mathrm{~m}$ sodium chloride. The fractions obtained from several series of the chromatography with samples were pooled and subjected to the next step for purification.

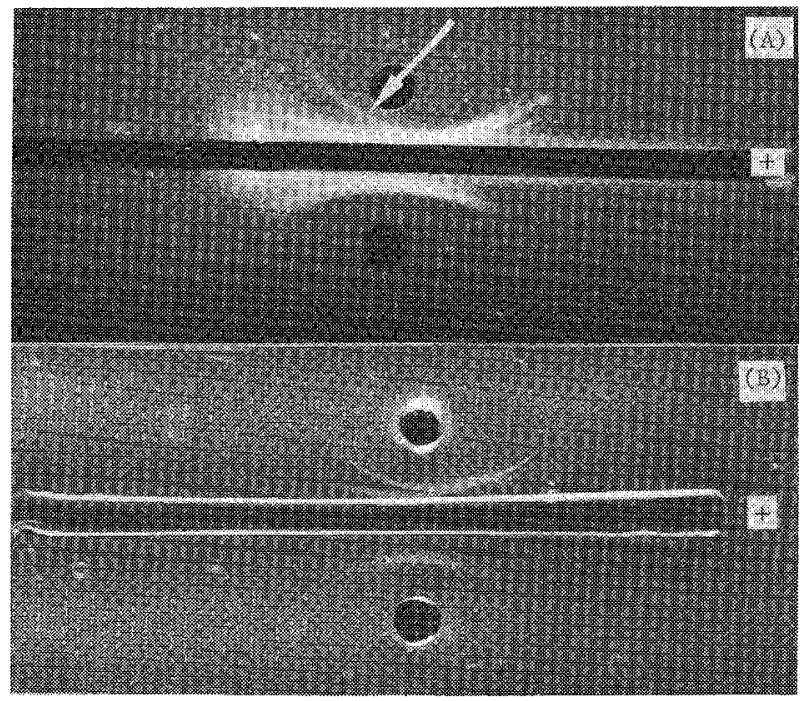

FIG. 1. Immunoelectrophoresis of Acetone Preparation (A) and Zymolyase Digest (B).

The upper well contained untreated sample and the lower well contained the sample heated at $100^{\circ} \mathrm{C}$ for $10 \mathrm{~min}$. The precipitation reaction was developed against anti-yeast serum at $4 . \mathrm{C}$ for 2 days. An arrow indicates the precipitin line cut out for the immunization of a rabbit in order to prepare anti-TLA serum. 
2. Immunoaffinity chromatography. An aliquot $(30 \mathrm{mg} / 30 \mathrm{ml}$ of $0.1 \mathrm{M}$ sodium chloride in the buffer described above) of the TLA-fraction obtained above was applied to an immunoadsorbent column $(1.7 \times 3.5 \mathrm{~cm})$ equilibrated with $0.1 \mathrm{M}$ Tris- $\mathrm{HCl}$ buffer $(\mathrm{pH} 8.0$ ). The column was washed with the same buffer until the effluent showed no absorbance at $240 \mathrm{~nm}$, and then eluted with $0.2 \mathrm{M}$ glycine buffer $(\mathrm{pH} 2.8$ ) containing $0.5 \mathrm{M}$ sodium chloride. The $\mathrm{pH}$ of the eluate was adjusted to 7.0 with $0.1 \mathrm{~N}$ sodium hydroxide and the eluate was dialyzed against water and lyophilized. A typical elution profile is shown in Fig. 2. The TLA recovered was about $200 \mu \mathrm{g}$ per one operation, and the column was available for repeating the chromatography 8 times.

\section{Homogeneity of TLA isolated}

The homogeneity of the purified TLA was examined by SDS-polyacrylamide gel electrophoresis and immunoelectrophoresis as shown in Fig. 3A and 3B. The TLA behaved as

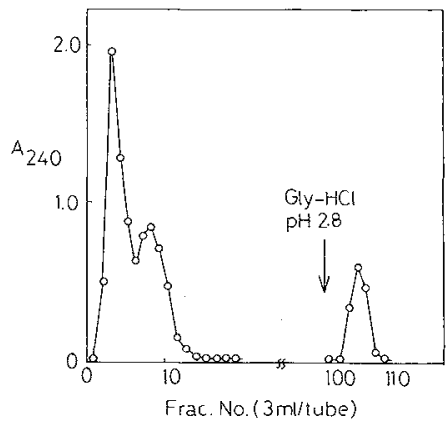

FIG. 2. A Typical Elution Profile of TLA from an Antibody-immobilized Sepharose Column.

The fraction from DEAE-cellulose was applied to the antibody-immobilized Sepharose column equilibrated with $0.1 \mathrm{M}$ Tris- $\mathrm{HCl}$ buffer ( $\mathrm{pH} 8.0$ ) containing $0.5 \mathrm{M} \mathrm{NaCl}$. TLA was eluted with $0.2 \mathrm{M}$ glycine- $\mathrm{HCl}$ buffer (pH 2.8) containing $0.5 \mathrm{M} \mathrm{NaCl}$.

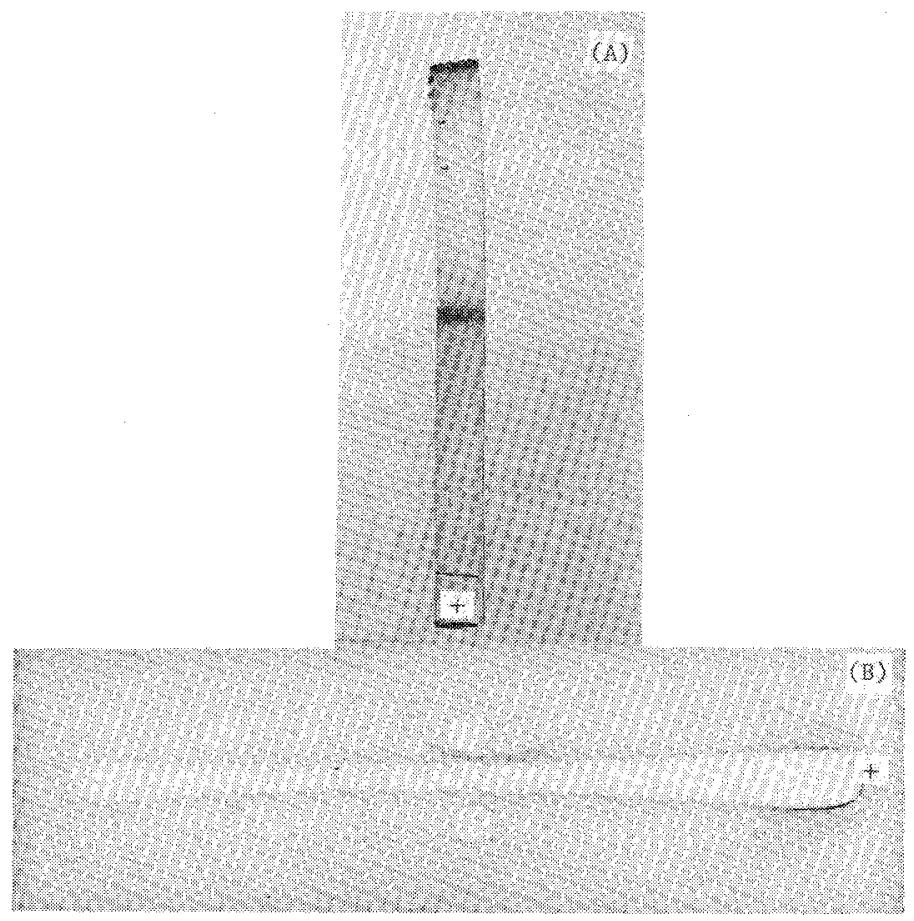

FIG. 3. SDS-polyacrylamide Gel Electrophoresis (A) and Immunoelectrophoresis (B) of Purified TLA.

(A) SDS-gel electrophoresis was performed in $0.1 \mathrm{M}$ phosphate buffer ( $\mathrm{pH} 7.2$ ) containing $0.1 \%$ SDS on $5 \%$ polyacrylamide gel. Electrophoresis was carried out at $8 \mathrm{~mA}$ per column for $5 \mathrm{hr}$. The gel was stained with Coomassie Brilliant Blue G-250 for protein.

(B) Immunoelectrophoresis was carried out in $1 \%$ agarose at $5 \mathrm{~mA}$ per plate $(2.5 \times 7.5 \mathrm{~cm})$ for $60 \mathrm{~min}$. The upper well contained non-heated TLA, and the lower well TLA heated at $100^{\circ} \mathrm{C}$ for $10 \mathrm{~min}$. The precipitation reaction was developed against anti-yeast serum. 
a single component on SDS-polyacrylamide gel electrophoresis. In immunoelectrophoresis also, the TLA gave a single precipitin line against an anti-yeast serum. These results indicate that the TLA was purified to a homogeneous state.

\section{Molecular weight of TLA}

The molecular weight of TLA estimated by SDS-polyacrylamide gel electrophoresis and gel filtration was $1.45 \times 10^{5}$ and $1.5 \times 10^{5}$, respectively.

\section{Amino acid composition}

The amino acid composition of TLA is summarized in Table I. Histidine, arginine,

TABLe I. Amino Acid Composition of TLA

Values given are numbers of amino acid residues per mol of protein.

\begin{tabular}{lc}
\hline Amino acid & Number of residues \\
\hline Lys & 2.6 \\
His & 0 \\
Arg & 0 \\
Cys $/ 2$ & 0 \\
Asp & 10.9 \\
Thr & 7.5 \\
Ser & 14.8 \\
Glu & 20.8 \\
Pro & 0.4 \\
Gly & 25.6 \\
Ala & 5.6 \\
Val & 4.2 \\
Met & 0 \\
Ile & 2.7 \\
Leu & 2.0 \\
Tyr & 1.2 \\
Phe & 1.8 \\
\hline
\end{tabular}

Tryptophan was not determined.

Table II. Sugar Composition of TLA

The relative amount of each residue was calculated assuming the total peak area to be 100 .

\begin{tabular}{lc}
\hline \multicolumn{1}{c}{ Sugars } & Relative amount of sugar $(\%)$ \\
\hline Fucose & 11 \\
Mannose & 24 \\
Galactose & 35 \\
$N$-Acetylglucosamine & 18 \\
Unknown & 12 \\
\hline
\end{tabular}

half-cystine and methionine were absent. TLA was characterized by high contents of glycine, glutamic acid, serine and aspartic acid.

\section{Sugar composition}

The total content of sugar was $25.5 \%$ and consisted of galactose, mannose, $\mathrm{N}$ acetylglucosamine and fucose in decreasing order. TLA was characterized by a high content of galactose $(35 \%)$.

\section{Immunological properties of TLA}

In order to compare the antigenic determinants of TLA with those of mannan, the Ouchterlony immunodiffusion test was carried

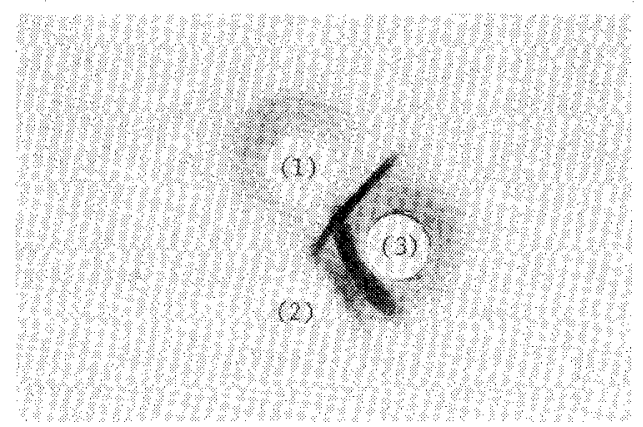

FIG. 4. Immunological Cross-reactivity Test.

Ouchterlony immunodiffusion analysis was performed using purified TLA, a mannan preparation and anti-yeast serum. Diffusion was carried out in $1 \%$ agar at $5^{\circ} \mathrm{C}$ for 2 days. Each wells contained (1) TLA, (2) mannanpreparation and (3) anti-yeast serum.

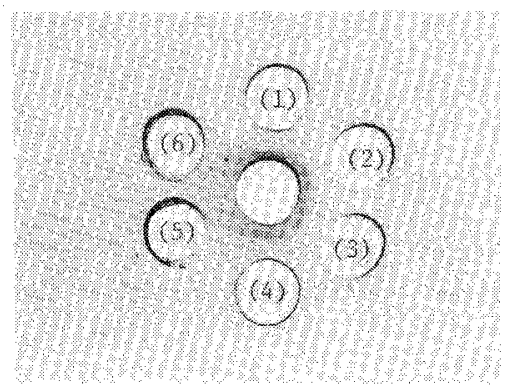

FIG. 5. Effect of Heating on the Formation of Precipitin Lines of TLA.

Purified TLA dissolved in water $(50 \mu \mathrm{g} / 0.5 \mathrm{ml})$ was heated at various temperatures for $10 \mathrm{~min}$ and an aliquot was diffused in agar gel. TLA used: (1) not-heated; (2) $60^{\circ} \mathrm{C}$; (3) $70^{\circ} \mathrm{C}$; (4) $80^{\circ} \mathrm{C}$; (5) $90^{\circ} \mathrm{C}$ and (6) $100^{\circ} \mathrm{C}$. The center well contained anti-TLA serum. The precipitation reaction was developed at $4^{\circ} \mathrm{C}$ for 2 days. 
out using anti-yeast serum, as shown in Fig. 4. TLA gave a sharp precipitin line, but the mannan gave several broad recipitin lines against the antisera. The line formed between TLA and anti-yeast serum did not fuse with any of the lines formed against mannan. Figure 5 shows the effect of heating on antigenicity of TLA. A clear precipitin line was observed for TLA heated at temperatures

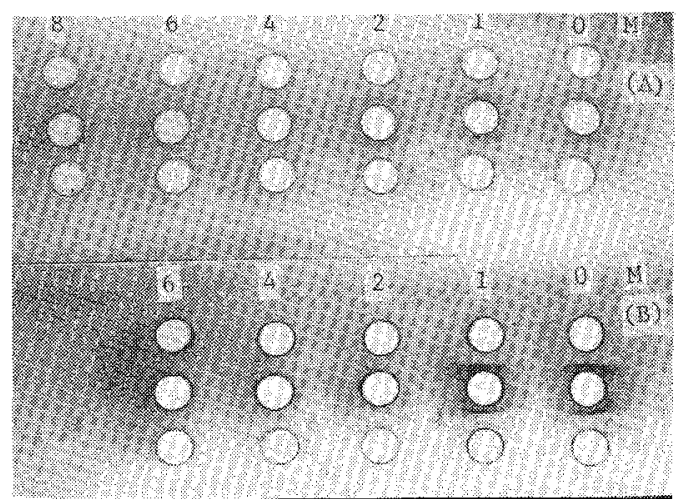

FIG. 6. Effect of Urea (A) and Guanidine Hydrochloride (B) on Antigenicity of TLA.

Purified TLA $(50 \mu \mathrm{g})$ was dissolved in $0.5 \mathrm{ml}$ of $0,1,2,4,6$ and $8 \mathrm{M}$ urea or $0,1,2,4$ and $6 \mathrm{~m}$ guanidine hydrochloride and incubated at $37^{\circ} \mathrm{C}$. After incubation for $1 \mathrm{hr}$, the solutions were dialyzed against water for 2 days at $4^{\circ} \mathrm{C}$, using visking tube (8/32), and an aliquot was diffused against anti-TLA serum.

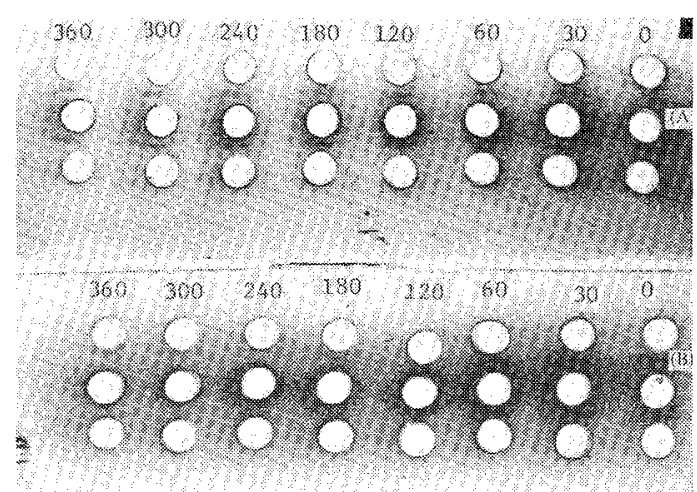

Fig. 7. Effect of Periodate Oxidation on the Antigenicity of TLA (A) and Mannan-preparation (B).

(A) Upper and lower wells contained oxidized TLA for the times indicated (min). Central wells contained antiTLA serum.

(B) Upper and lower wells contained the mannanpreparation oxidized for the times indicated ( $\mathrm{min}$ ). Central wells contained anti-yeast serum. lower than $80^{\circ} \mathrm{C}$ for $10 \mathrm{~min}$, but no line was observed for TLA heated at temperatures above $90^{\circ} \mathrm{C}$.

The effect of urea and guanidine hydrochloride on antigenicity of TLA is shown in Fig. 6. A precipitin line was formed for TLA incubated with $2 \mathrm{M}$ urea or $1 \mathrm{M}$ guanidine hydrochloride, while no line was formed for TLA incubated with $4 \mathrm{M}$ or more of urea or $2 \mathrm{M}$ or more of guanidine hydrochloride.

To determine the locality of antigenic determinants, TLA was subjected to periodate

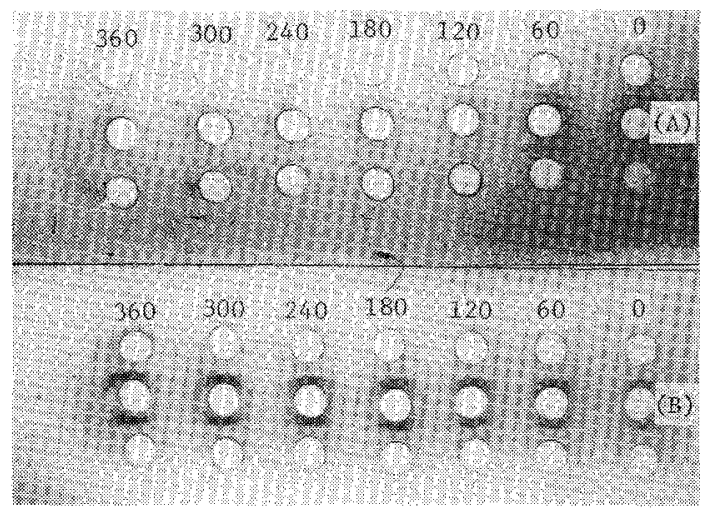

FIG. 8. Effect of Pronase Digestion on Antigenicity of TLA (A) and Mannan-preparation (B).

(A) Upper and lower wells contained purified TLA, digested for the respective times ( 0 to $360 \mathrm{~min}$ ). Central wells contained anti-TLA serum.

(B) Upper and lower wells contained the mannanpreparation digested for the respective times $(0$ to $360 \mathrm{~min}$ ). Central wells contained anti-yeast serum.

Table III. AgGlutination Reaction by ANTI-TLA SERUM

\begin{tabular}{cccc}
\hline $\begin{array}{c}\text { Dilution } \\
\text { of } \\
\text { antiserum }\end{array}$ & Blank & \multicolumn{2}{c}{$\begin{array}{c}\text { Agglutination reaction } \\
\text { after absorption by }\end{array}$} \\
\cline { 3 - 4 } & & Fresh yeast & Heated yeast \\
\hline 10 & $++^{a}$ & + & ++ \\
20 & ++ & \pm & ++ \\
40 & ++ & - & ++ \\
80 & ++ & - & ++ \\
160 & ++ & - & + \\
320 & + & - & \pm
\end{tabular}

a The states of agglutination: ++ , detected with the naked eye; + , detected clearly but under a microscope; \pm , detected slightly under a microscope; - , not detected. 


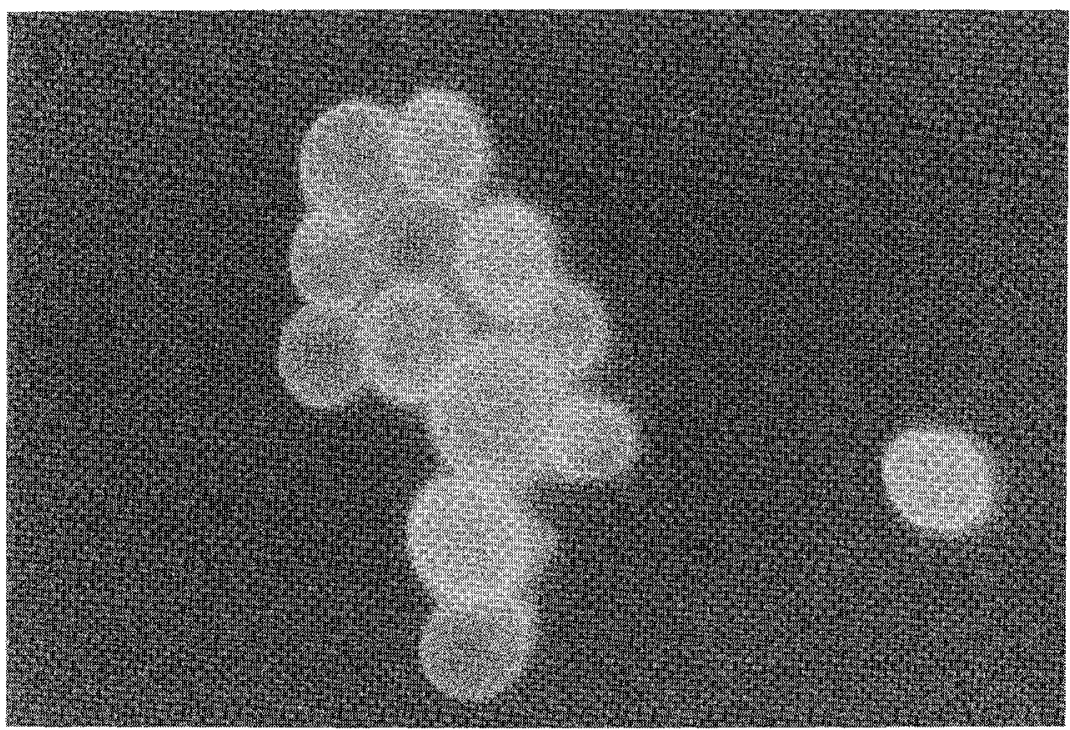

FIG. 9. Indirect Immunofluorescence Staining of Yeast Cells.

Yeast cells were incubated with anti-TLA serum at $37^{\circ} \mathrm{C}$ for $60 \mathrm{~min}$ and washed three times with saline. Then FITC-labeled anti-rabbit IgG serum was added to sedimented cells and incubated at $37^{\circ} \mathrm{C}$ for $30 \mathrm{~min}$. After washing the cells three times with saline, one drop of the suspension in saline was placed under a cover glass and inspected under a fluorescence microscope.

oxidation and Pronase digestion. The effect of periodate oxidation on the antigenicities of TLA and a mannan-preparation is shown in Fig. 7. The mannan-preparation was affected by oxidation with periodate so significantly that the precipitin lines were not formed after 120 min of oxidation, but TLA was not affected and formed a clear line against anti-TLA serum even after $3 \mathrm{hr}$ of oxidation.

The effect of Pronase-digestion on antigenicities of TLA and mannan-preparation is shown in Fig. 8. TLA did not form a precipitin line on 60 min of digestion, but the mannanpreparation formed clear lines throughout the digestion.

In order to investigate the contribution of TLA to the agglutination reaction of yeast cells, the reaction by anti-TLA serum was examined. As shown in Table III, the antiTLA serum diluted 320 -fold agglutinated fresh yeast cells. When the antibodies of TLA were absorbed by fresh yeast cells, the agglutination reactivity disappeared on dilution above 20 fold, but when the anti-TLA was absorbed by heated yeast cells, the reactivity remained even on dilution up to 160 -fold. In fact, the surface of yeast was stained by immunofluorescence staining with anti-TLA serum as shown in Fig. 9. These fingings suggest that TLA is located on the outer layer of the yeast cell surface and its antigenicity is lost almost completely on heating at $100^{\circ} \mathrm{C}$ for $10 \mathrm{~min}$.

\section{DISCUSSION}

In the present experiments, a thermolabile antigen was extracted from a precipitin line on immunoelectrophoresis using the antiserum against whole cells of fresh yeast, and a glycoprotein responsible for the immune reaction was isolated by immunoadsorbent affinity chromatography using a rabbit antiserum. The protein moiety was considered to display thermolabile antigenicity (TLA).

TLA was inferred to be located on the surface of the yeast cell, because the anti-TLA serum agglutinated fresh yeast cells and the cell surface of fresh yeast was stained with fluorescence in the test using anti-TLA rabbit serum and FITC-labeled anti-rabbit IgG. The 
mannan fraction of yeast cell wall has so far been reported to be the antigen of the cell surface. Also, the antigenic determinant has been suggested to be oligosaccharide of the side chain in mannan. ${ }^{18)}$ The existence of TLA on the yeast cell surface has been inferred by some investigators ${ }^{4,19)}$ but no antigenic substance has so far been isolated.

It is clear that TLA differs from the antigenic mannan preparation from cell wall in the following ways. 1 . TLA is thermolabile. 2 . The mannan preparation lost the antigenicity completely, when treated with $0.02 \mathrm{M}$ sodium periodate at $0^{\circ} \mathrm{C}$ in $2 \mathrm{hr}$ in the dark, but TLA retained the antigenicity completely under the same conditions. 3. In digestion with Pronase, the mannan preparation retained the antigenicity, but TLA lost the antigenicity completely in $1 \mathrm{hr}$. 4. TLA lost the antigenicity when treated with such protein denaturants as urea and guanidine hydrochloride. The above findings may indicate that the protein of TLA plays an important role in the antigenicity of TLA.

Two types of manno-protein have been obtained from yeast cell wall. One is a structural component and the other is a mannoprotein enzyme. ${ }^{18)}$ TLA is distinctly different from these cell wall manno-proteins in the following ways: 1 . The total sugar content of TLA is only $25.5 \%$, the moiety consists of various sugars such as galactose, mannose, $\mathrm{N}$ acetylglucosamine, and fucose, while the structural manno-protein is generally composed of about $90 \%$ of mannose and $5 \sim 10 \%$ of protein. ${ }^{18)}$ Manno-protein enzymes, such as invertase and phosphatase, are composed of $50 \sim 70 \%$ of mannan. ${ }^{18)} 2$. TLA has a molecular weight of $145,000 \sim 150,000$ and is not divided into subunits on SDS-gel electrophoresis, while the molecular weight of the structural manno-protein greatly varies from 25,000 to $500,000 .^{20)} 3$. TLA is located on the surface of the yeast cell so that it reacts with anti-TLA, while the manno-protein enzyme exists in a matrix fabricated with the structural manno-protein. ${ }^{18)}$

TLA is constituted from only 13 species of amino acid and 4 of them (Gly, Glu, Ser and Asp) comprise $70 \%$ of the total amino acid content. The unusual amino acid composition of TLA suggests that the major amino acids play a certain role in the cell surface like the outer membrane proteins of bacteria. ${ }^{21)}$ As for the outer surface of yeast cells, a model of a layer composed of mannan, protein and phosphate has been proposed by Kidby et al., ${ }^{22)}$ but the relationship between the protein in the model and the TLA purified in the present work remains to be investigated. The existence of TLA on the cell surface indicates that the surface of yeast cells is more complicated than the model presented by Kidby et al. A study on properties and localization of TLA may give rise to clues for the elucidation of the structure and function of the yeast cell surface.

Acknowledgment. We wish to express our thanks to the Research Laboratory of Kirin Brewery Co. for the gift of Zymolyase.

\section{REFERENCES}

1) S. Peat, W. J. Whelan and T. E. Edwards, J. Chem. Soc., 29 (1961).

2) C. E. Ballou, J. Biol. Chem., 245, 1197 (1970).

3) S. Suzuki, H. Sunayama and T. Saito, Japan $J$. Microbiol., 12, 19 (1968).

4) T. Tsuchiya, Japan J. Bacteriol., 19, 253 (1964) (in Japanese).

5) M. Takakuwa, H. Koshitani and Y. Tamai, Mem. Coll. Agr., Ehime Univ., 21, 179 (1976).

6) M. Takakuwa, H. Koshitani and Y. Tamai, $J$. Ferment. Technol., 54, 856 (1976).

7) Y. Tamai, T. Nakashima, M. Takakuwa and A. Misaki, Agric. Biol. Chem., 44, 49 (1980).

8) T. E. Edwards, "Methods in Carbohydrate Chemistry," Vol. V, ed. by R. L. Whistler, Academic Press Inc., New York, N.Y., 1965, pp. 178 179.

9) O. Ouchterlony, Prog. Allergy, 6, 30 (1965).

10) P. Andrews, Biochem. J., 96, 595 (1965).

11) K. Weber and M. Osborn, J. Biol. Chem., 244, 4406 (1969).

12) O. H. Lowry, N. J. Rosebrough, A. L. Farr and R. J. Randall, J. Biol. Chem., 193, 265 (1951).

13) M. Dubois, K. A. Gilles, J. K. Hamilton, P. A. Rebers and F. Smith, Anal. Chem., 28, 350 (1956).

14) D. H. Spackman, W. H. Stein and S. Iwanaga, $J$. Biochem., 86, 1615 (1979).

15) R. E. Chambers and J. R. Clamp, Biochem. J., 125, 1009 (1971). 
16) C. C. Sweeley, R Bentley, M. Mikata and W. W. Wells, J. Am. Chem. Soc., 85, 2497 (1963).

17) H. Igarashi, T. Morita and S. Moore, Anal. Chem., p. 1190 (1958).

18) C. E. Ballou and W. C. Raschke, Science, 184, 127 (1974).

19) Y. Fukazawa, Japan J. Bacteriol., 11, 245 (1956) (in
Japanese).

20) T. R. Thieme and C. E. Ballou, Biochemistry, 11, 1115 (1972).

21) V. Braun and V. Bosch, Proc. Natl. Acad. Sci. USA, 69, 970 (1972).

22) D. K. Kidby and R. Davies, J. Gen. Microbiol., 61, $327(1970)$. 